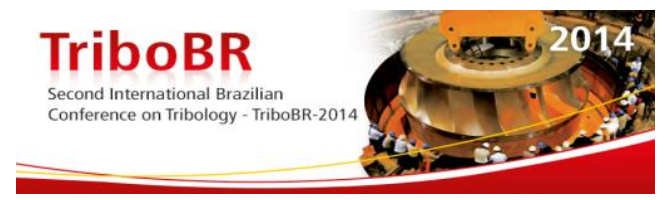

\title{
MICRO-ABRASIVE WEAR BEHAVIOUR OF AN IRON ALUMINIDE ALLOY UNDER CONDITIONS OF ROOM AND ELEVATED TEMPERATURES*
}

\author{
Ronaldo Câmara Cozza ${ }^{1}$ \\ Lucas Cremonese Rodrigues ${ }^{2}$ \\ Cláudio Geraldo Schön ${ }^{3}$
}

\begin{abstract}
The aim of this work is to study the micro-abrasive wear behaviour of an iron aluminide alloy, seeking correlations between wear volume, coefficient of friction and temperature in ball-cratering wear testing. The experiments were conducted with specimens of iron aluminide alloy, a ball of AISI 52100 steel and abrasive slurry prepared with black silicon carbide (SiC) particles and glycerin. Different test conditions were defined, and during the experiments, the abrasive slurry was continuously agitated and fed between the specimen and the ball. The tangential $(T)$ and normal $(N)$ forces were monitored simultaneously throughout the tests, and the coefficient of friction $(\mu)$ acting in the tribological system "ball - abrasive particles specimen" was calculated using the equation $\mu=T / N$. The results indicated that $i$ ) the temperature played an important role on the wear volume and coefficient of friction, ii) with increasing temperature, decreases in the wear volume and coefficient of friction were observed, and iii) the abrasive wear mode in all wear craters was rolling abrasion, independent of the temperature.
\end{abstract}

Keywords: Iron aluminide alloy; Ball-cratering wear testing; Rolling abrasion; Wear volume; Coefficient of friction.

1 Mechanical Engineer, Doctor, Post-Doctoral Student, Departamento de Engenharia Metalúrgica e de Materiais, Escola Politécnica da USP, São Paulo, SP, Brazil; Professor Adjunto I, Departamento de Engenharia Mecânica, Centro Universitário da FEl, São Bernardo do Campo, SP, Brazil; Professor Associado I, Departamento de Fabricação Mecânica, CEETEPS - FATEC-Mauá, Mauá, $S P$, Brazil.

2 Mechanical Engineer, Departamento de Engenharia Mecânica, Prensa Jundiaí S.A., Campo Limpo Paulista, SP, Brazil.

3 Physical, Doctor, Professor Associado 3, Departamento de Engenharia Metalúrgica e de Materiais, Escola Politécnica da USP, São Paulo, SP, Brazil.

* Technical contribution to the $2^{\text {nd }}$ International Brazilian Conference on Tribology - TriboBR 2014, November $3^{\text {rd }}$ to $5^{\text {th }}, 2014$, Foz do Iguaçu, PR, Brazil. 


\section{INTRODUCTION}

Nomenclature and units used for the ball-cratering wear tests of this research

\begin{tabular}{|ll|}
\hline$b$ & Diameter of the wear crater [mm] \\
$C$ & Concentration of the abrasive slurry \\
$D$ & Diameter of the ball [mm] \\
$h$ & Depth of the wear crater [mm] \\
$H$ & Hardness of the material [GPa]; [HV] \\
$n$ & Ball rotational speed [rpm] \\
$N$ & Normal force [N] \\
$R$ & Radius of the ball [mm] \\
$S$ & Sliding distance [m] \\
$t$ & Test time [s] \\
$T$ & Tangential force (friction force) $[\mathrm{N}]$ \\
$T_{e}$ & Temperature [ $\left.{ }^{\circ} \mathrm{C}\right]$ \\
$V$ & Tangential sliding velocity [m/s] \\
$V$ & Wear volume (volume of the wear crater) $\left[\mathrm{mm}^{3}\right]$ \\
& \\
$\mathrm{Greek}$ & letter \\
$\mu$ & Coefficient of friction \\
\hline
\end{tabular}

The ball-cratering wear test has gained large acceptance at universities and research centres and is widely used in studies focusing on the abrasive wear of different metallic and non-metallic materials. Figure 1 presents a schematic diagram of the principles of the ball-cratering abrasive wear test: a rotating ball is forced against the specimen being tested, and an abrasive slurry is supplied between the ball and the specimen during the experiments. In Figure $1, h$ is the depth of the wear crater.

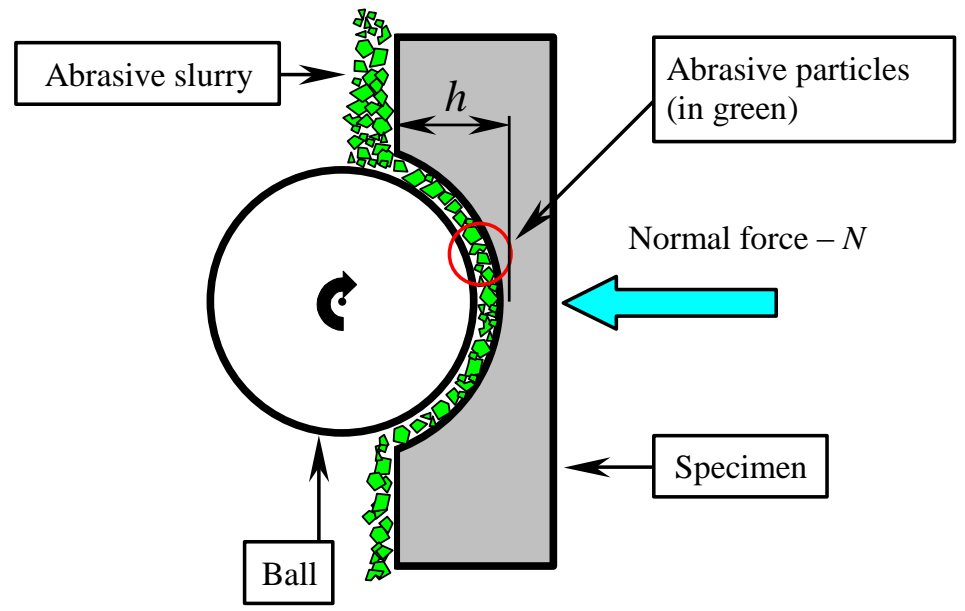

Figure 1. Micro-abrasive wear test: representative figure of the operating principle and the abrasive particles between the ball and the specimen.

The aim of the micro-abrasive wear test is to generate "wear craters" on the specimen. Figure 2 presents an image of such craters, together with an indication of the crater diameter (b) (Figure 2a [1,2]) and the wear volume (V) (Figure 2b [3]).

The diameter of the wear crater is commonly measured using optical microscopy, and the wear volume may be determined as a function of $b$, using Equation 1 [4], where $R$ is the radius of the ball.

* Technical contribution to the $2^{\text {nd }}$ International Brazilian Conference on Tribology - TriboBR 2014, November $3^{\text {rd }}$ to $5^{\text {th }}$, 2014, Foz do Iguaçu, PR, Brazil. 

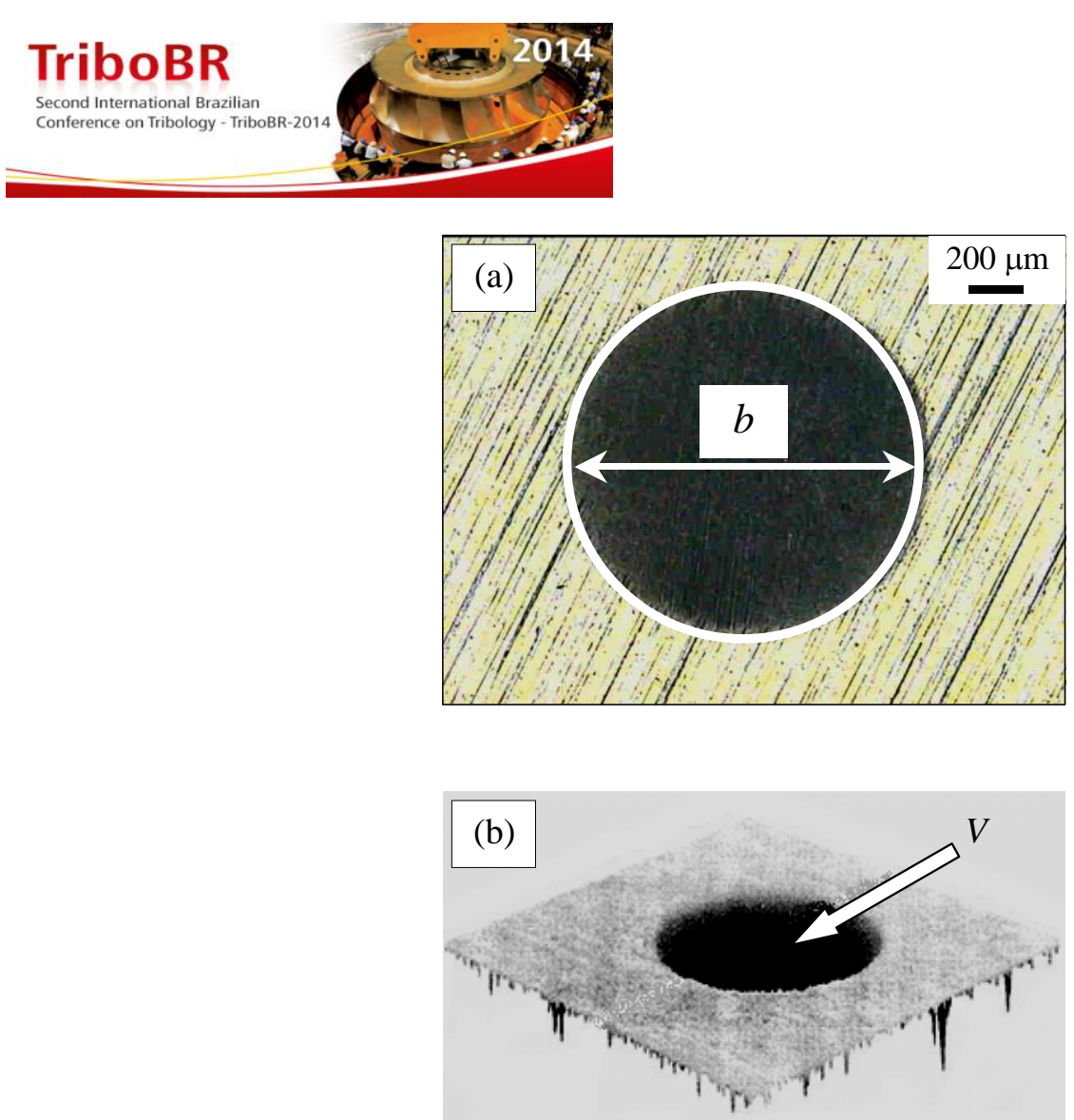

Figure 2. Images of wear craters: (a) diameter $-b[1,2]$ and (b) wear volume $-V[3]$.

$$
V \cong \frac{\pi b^{4}}{64 R} \quad \text { for } b<<R
$$

In ball-cratering wear testing, two abrasive wear modes are observed on the surface of the wear crater: "grooving abrasion", which results when the abrasive particles slide on the specimen (Figure 3a [5]), and "rolling abrasion", which is reported when the abrasive particles roll onto the surface of the specimen (Figure $3 b$ ). In addition, depending on test conditions, "rolling abrasion" and "grooving abrasion" wear modes can occur simultaneously [6-8] (Figure 3c [6]).

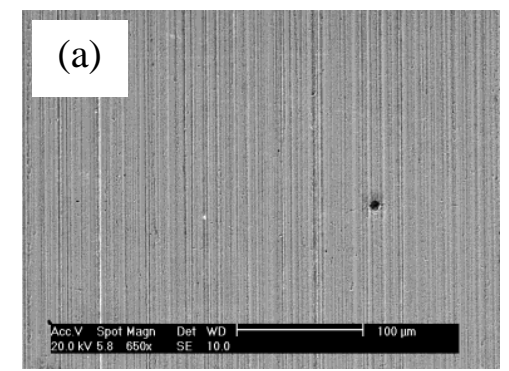

Figure 3. Abrasive wear modes: (a) grooving abrasion [5], simultaneous action of rolling abrasion and grooving abrasion [6].

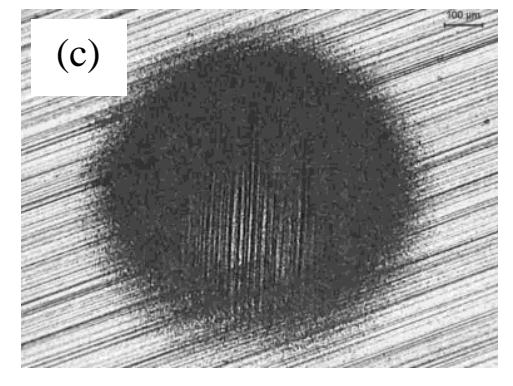

(b) rolling abrasion and (c) the

Using the ball-cratering wear tests, the wear behaviour of the materials can be analysed based on the dimensions of the wear crater and/or on the actions of the abrasive wear modes; in addition, in other segments of research, the advantages of use of the aluminide alloys in mechanical and metallurgical applications are observed. In reality, in recent decades, aluminide alloys of cobalt (Co), iron (Fe), niobium ( $\mathrm{Nb}$ ), nickel ( $\mathrm{Ni}$ ) and titanium (Ti) have been thoroughly studied, primarily due to the possibility of adoption as structural materials subjected to high temperatures [9].

* Technical contribution to the $2^{\text {nd }}$ International Brazilian Conference on Tribology - TriboBR 2014, November $3^{\text {rd }}$ to $5^{\text {th }}, 2014$, Foz do Iguaçu, PR, Brazil. 


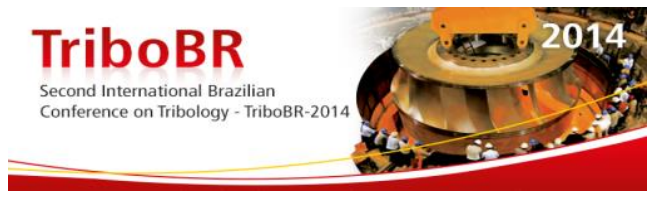

These aluminide alloys exhibit a high concentration of aluminium (Al) [9] and are able to form a continuous and adherent layer of alumina $\left(\mathrm{Al}_{2} \mathrm{O}_{3}\right)$ on a surface exposed to air or to atmospheres containing oxygen. Beyond the advantage of this layer of alumina to protect materials against corrosion and high temperatures of oxidation [9-11], because it exhibits greater thermodynamic stability than chromium oxide $\left(\mathrm{Cr}_{2} \mathrm{O}_{3}\right)$, the aluminide alloys have smaller densities, high fusion points and exhibit considerable mechanical and metallurgical properties [11-13], due to their crystalline structure.

In particular, the mechanical properties of steels containing iron aluminides can be handled by variation of the percentage of aluminium, the type of heat treatment and the grain size $[14,15]$, causing, as a function of these parameters, certain materials to be directed to specific mechanical-metallurgical applications.

In carbon-steels, decreases in the yield strength stress $\left(\sigma_{\mathrm{y}}\right)$ and the ultimate stress $(\sigma u)$ are observed as a function of the increasing temperature; this phenomenon occurs with the maintenance of the value of the Young's Modulus $(E)$. For example, the insertion of iron aluminides $\left(\mathrm{Fe}_{3} \mathrm{Al}\right)$ reach a limit of approximately $500^{\circ} \mathrm{C}$, while the magnitudes of $\sigma \mathrm{y}$ and $\sigma \mathrm{u}$ remain constant or increase [16-19].

Observing these important technical features of materials that contain aluminides [9-21], the purpose of this work is to study the micro-abrasive wear behaviour of an iron aluminide alloy under conditions of room and elevated temperatures.

\section{EQUIPMENT, MATERIALS AND METHODS}

\subsection{Micro-abrasive Wear Test Equipment}

A ball-cratering apparatus in the free-ball configuration (Figure 4) was designed and constructed for the micro-abrasive wear tests.

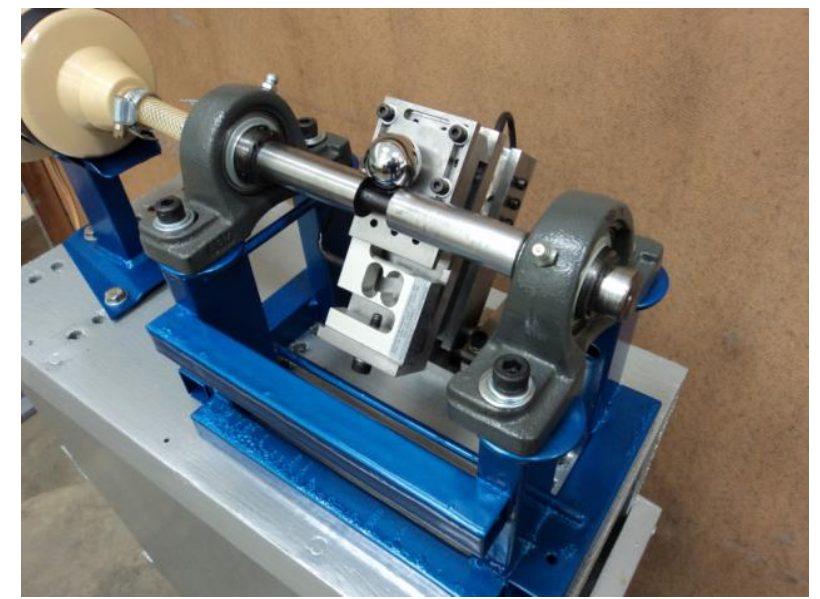

Figure 4. Ball-cratering apparatus in the free-ball configuration designed and constructed for the micro-abrasive wear tests.

Two load cells were used in the ball-cratering equipment: one load cell is used to control the normal force $(N)$, and the other load cell is used to measure the tangential force $(T)$ developed during the experiments. "Normal" and "tangential" force load cells have a maximum capacity of $50 \mathrm{~N}$ and an accuracy of $0.001 \mathrm{~N}$. The values of " $N$ " and " $T$ " are read via a readout system.

* Technical contribution to the $2^{\text {nd }}$ International Brazilian Conference on Tribology - TriboBR 2014, November $3^{\text {rd }}$ to $5^{\text {th }}$, 2014, Foz do Iguaçu, PR, Brazil. 


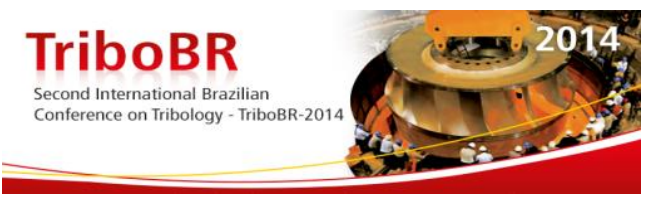

\subsection{Materials}

The tested specimen was a Fe30AICr (\%at) iron aluminide alloy [22], and, as a counterbody, one ball made of AISI 52100 steel was used, with a diameter of $D=25.4 \mathrm{~mm}(D=1 ")$.

Figures 5a [22] and 5b [23-26] present images of the microstructures of the specimen and the ball, respectively, together their chemical composition.

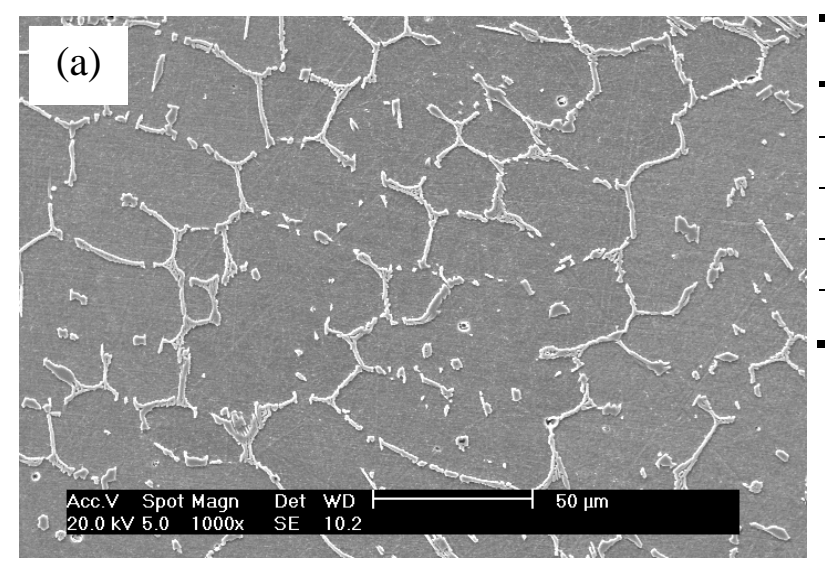

\begin{tabular}{cc}
\hline Chemical Element & \% (in weight) \\
\hline $\mathrm{Al}$ & 14.63 \\
\hline $\mathrm{Cr}$ & 7.82 \\
\hline $\mathrm{Mo}$ & 0.69 \\
\hline $\mathrm{C}$ & 0.20 \\
\hline $\mathrm{Fe}$ & 75.28 \\
\hline
\end{tabular}

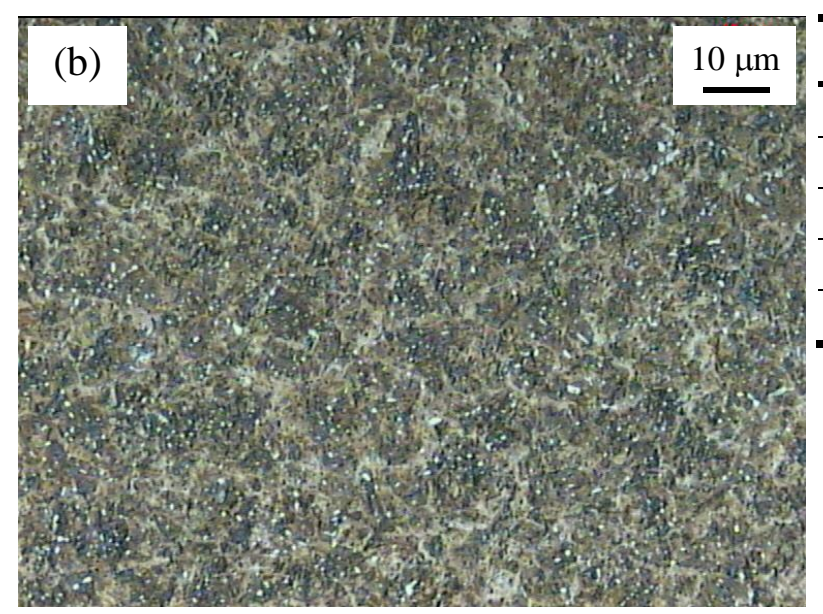

\begin{tabular}{|cc}
\hline Chemical Element & \% (in weight) \\
\hline $\mathrm{C}$ & 1.04 \\
\hline $\mathrm{Mn}$ & 0.35 \\
\hline $\mathrm{Si}$ & 0.25 \\
\hline $\mathrm{Cr}$ & 1.45 \\
\hline $\mathrm{Fe}$ & Balance \\
\hline
\end{tabular}

Figure 5. Microstructures and chemical compositions of the materials used in this work: (a) specimen of Fe30AICr iron aluminide alloy and (b) ball of AISI 52100 steel.

The abrasive slurry was prepared with abrasive particles of black silicon carbide $(\mathrm{SiC})$, with an average particle size of $3 \mu \mathrm{m}$, and glycerin. Figure $6[24,26]$ presents a micrograph of the abrasive particles (Figure 6a) and their abrasive particle size distribution (Figure 6b).

Table 1 presents the hardness $(H)$ of the materials used in this work (specimen [22], ball [23-26] and abrasive particles [24,26]).

Table 1. Hardness of the materials used in this work [22-26]

\begin{tabular}{ccc}
\hline & Material & Hardness $(H)-[\mathrm{GPa}][(\mathrm{HV})]$ \\
\hline Specimen & Fe30AICr iron aluminide alloy & $7.1(720)[22]$ \\
\hline Ball & AISI 52100 steel & $8.4(856)[23-26]$ \\
\hline Abrasive particles & SiC & $18.5-19(1886-1937)[24,26]$ \\
\hline
\end{tabular}

* Technical contribution to the $2^{\text {nd }}$ International Brazilian Conference on Tribology - TriboBR 2014, November $3^{\text {rd }}$ to $5^{\text {th }}$, 2014, Foz do Iguaçu, PR, Brazil. 

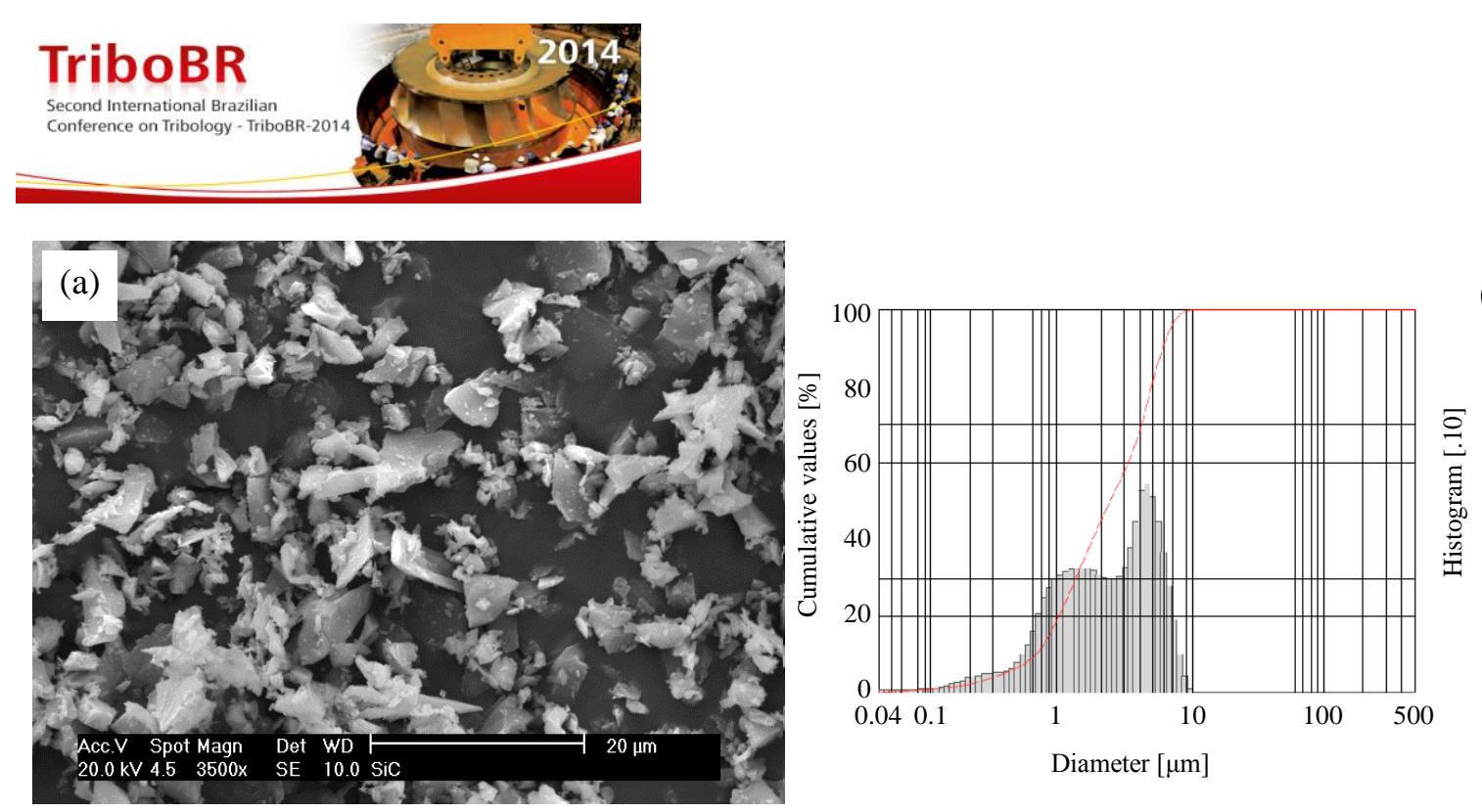

(b)

Figure 6. SiC abrasive particles [24,26]: (a) scanning electron micrograph and (b) particle size distribution.

\subsection{Micro-abrasive Wear Tests}

Table 2 presents the test conditions defined for the experiments conducted in this work.

Table 2. Test conditions defined for the ball-cratering wear experiments

\begin{tabular}{|c|c|c|c|}
\hline Test condition $\Rightarrow$ & 1 & 2 & 3 \\
\hline Normal force $-N[\mathrm{~N}]$ & 0.4 & 0.4 & 0.4 \\
\hline $\begin{array}{l}\text { Abrasive slurry concentration }-C \\
\text { (in volume) }\end{array}$ & $\begin{array}{l}35 \% \mathrm{SiC}+ \\
65 \% \text { glycerin }\end{array}$ & $\begin{array}{l}35 \% \mathrm{SiC}+ \\
65 \% \text { glycerin }\end{array}$ & $\begin{array}{l}35 \% \mathrm{SiC}+ \\
65 \% \text { glycerin }\end{array}$ \\
\hline Test time $-t[\mathrm{~min}]$ & 1 & 2 & 4 \\
\hline Temperature - $T e_{1}\left[{ }^{\circ} \mathrm{C}\right]($ room $)$ & 29 & 29 & 29 \\
\hline Temperature $-\mathrm{Te}_{2}\left[{ }^{\circ} \mathrm{C}\right]$ & 250 & 250 & 250 \\
\hline Ball rotational speed $-n[\mathrm{rpm}]$ & 70 & 70 & 70 \\
\hline Tangential sliding velocity $-v[\mathrm{~m} / \mathrm{s}]$ & 0.09 & 0.09 & 0.09 \\
\hline Sliding distance $-S[\mathrm{~m}]$ & 5.6 & 11.2 & 22.4 \\
\hline Number of repetitions & 3 & 3 & 3 \\
\hline
\end{tabular}

Three experiments were conducted for each value of $S$, according to the following test sequence: $5.6-5.6-22.4-11.2-11.2-22.4-22.4-11.2$ and $5.6 \mathrm{~m}$. In total, 18 micro-abrasive wear tests were performed: nine experiments at $T e_{1}=29^{\circ} \mathrm{C}$ (room temperature) and nine experiments at $T e_{2}=250^{\circ} \mathrm{C}$.

All tests were conducted without interruption, and the abrasive slurry was continuously agitated and fed between the ball and specimen.

For the experiments conducted at the elevated temperature $\left(T e_{2}=250^{\circ} \mathrm{C}\right)$, a heating stage was used to heat the specimen to the desired temperature, and the temperature was monitored using an infrared thermometer with a resolution of $5^{\circ} \mathrm{C}$. The apparatus that was designed and constructed to heat the specimen consists of an aluminium specimen-support block containing one 1,200 W ( 120 V) electrical heating element. The load cells were separated of the block of heating using a bakelite plate.

\footnotetext{
* Technical contribution to the $2^{\text {nd }}$ International Brazilian Conference on Tribology - TriboBR 2014, November $3^{\text {rd }}$ to $5^{\text {th }}, 2014$, Foz do Iguaçu, PR, Brazil.
} 


\subsubsection{Data acquisition and result analysis}

Both the normal force $(N)$ and the tangential force $(T)$ were monitored and registered constantly. Subsequently, the volume of wear $(V)$ was determined using Equation 1.

The coefficient of friction was determined using Equation 2, for the experiments conducted with the sliding distance of $S_{3}=22.4 \mathrm{~m}$.

Next, graphs of $V=f(S, T e)$ and $\mu=f(t, T e)$ were plotted.

$$
\mu=\frac{T}{N}
$$

\section{RESULTS AND DISCUSSION}

\subsection{Analysis of the Steady State of the Abrasive Wear}

Initially, the behaviours of the wear volume $(V)$ as a function of the sliding distance $(S)$ and temperature $(T e)-V=f(S, T e)$ were analysed, as presented in Figure 7.

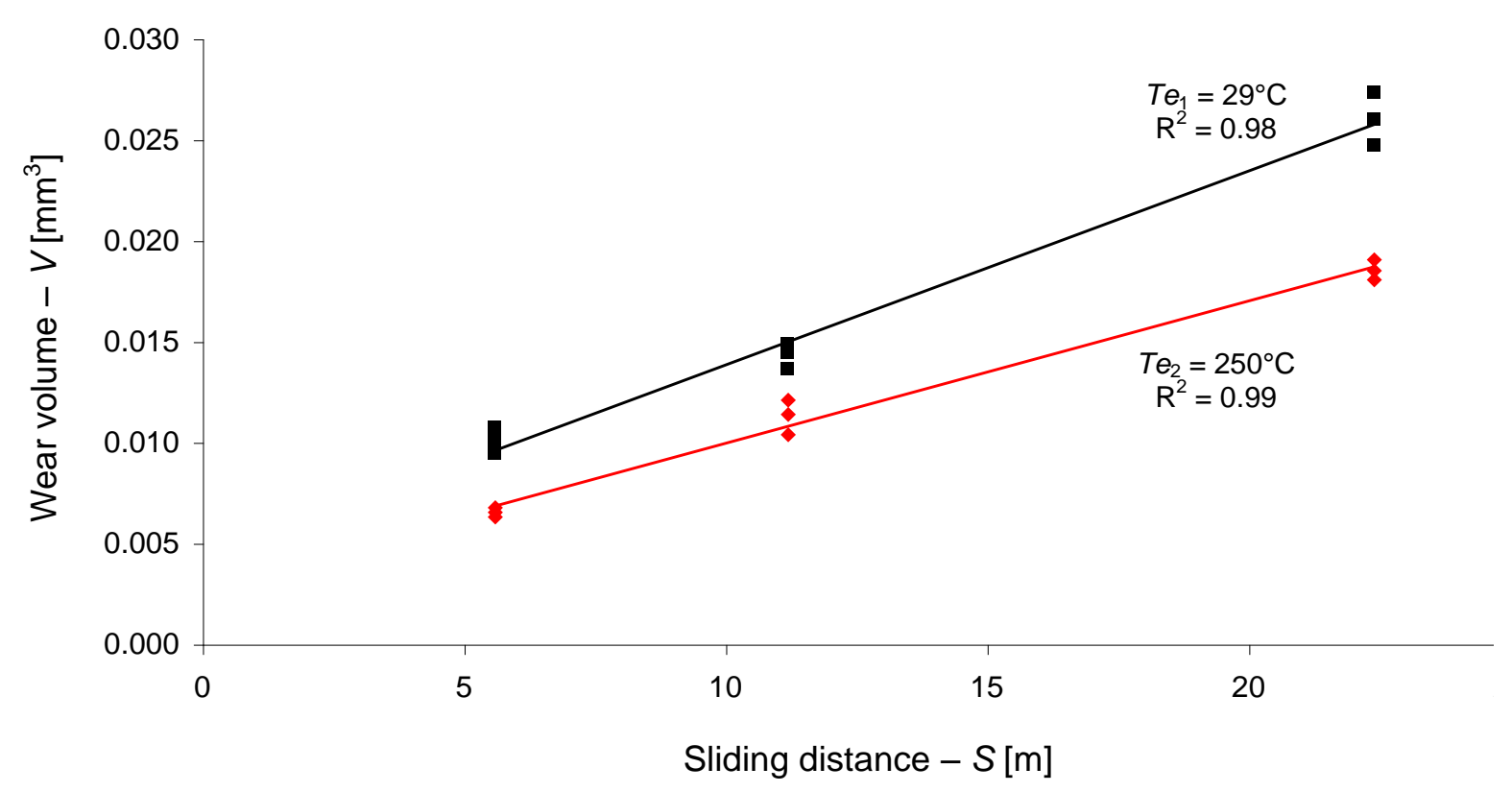

Figure 7. Graphics of the wear volume ( $V$ as a function of the sliding distance $(S)$ and the temperature $(T e)-V=f(S, T e)$.

In both cases, the wear volume presented a linear behaviour with the increase of the sliding distance, indicating the achievement of the steady state of the abrasive wear. In addition, the reproducibility obtained in the experiments of this work was directly influenced by the action of rolling abrasion in the wear craters, which, as reported by Bose and Wood [27], tends to produce results with relatively reliable reproducibility. In fact, the achievement of the steady state of the abrasive wear is important for the analysis of the results obtained in the micro-abrasive wear tests by rotating ball because the phenomena involved ceases to be random and exhibit foreseeable behaviours.

* Technical contribution to the $2^{\text {nd }}$ International Brazilian Conference on Tribology - TriboBR 2014, November $3^{\text {rd }}$ to $5^{\text {th }}, 2014$, Foz do Iguaçu, PR, Brazil. 


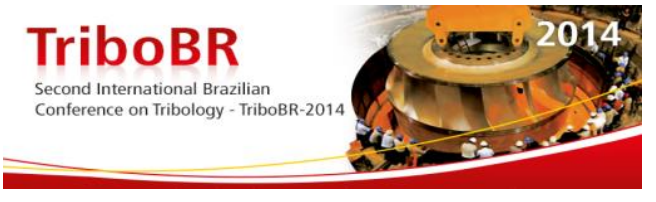

\subsection{Analysis of the Behaviour of the Wear Volume}

By analysing Figure 7, it is possible to note that the wear volume decreased with the increase of the test temperature - Te.

The rolling abrasion, which is the abrasive wear observed in all wear craters of this work, can be related to the "cutting" and "micro-fatigue" [28] that occurs due to repetitive rolling of the abrasive particles on the surface of the wear crater, e.g., the wear that occurs due to plastic deformation [29].

With the increase in the temperature, the material of the specimen exhibits larger ductility, consequently favouring a larger degree of plastic deformation than removal of material. This high capacity of plastic deformation that the specimen material acquires with the increase of the test temperature favours the occurrence of "microfatigue" (due to the actions of the abrasive particles) which, in addition to being the wear mechanism of smaller severity when compared with the "cutting", is consequently associated with smaller wear rates. To remove a certain quantity of material under the occurrence of micro-fatigue (plastic deformation), a larger number of abrasive particles must slide or to roll in the same region of wear.

\subsection{Analysis of the Actions of the Abrasive Wear Modes}

Figure 8a presents an example of a wear crater generated in the micro-abrasive wear tests via a rotating ball. Figures $8 \mathrm{~b}$ and $8 \mathrm{c}$ show images obtained using a scanning electron microscope (SEM) in which the occurrence of rolling abrasion is observed for the conditions of $T e_{1}=29^{\circ} \mathrm{C}$ and $T e_{2}=250^{\circ} \mathrm{C}$, respectively.
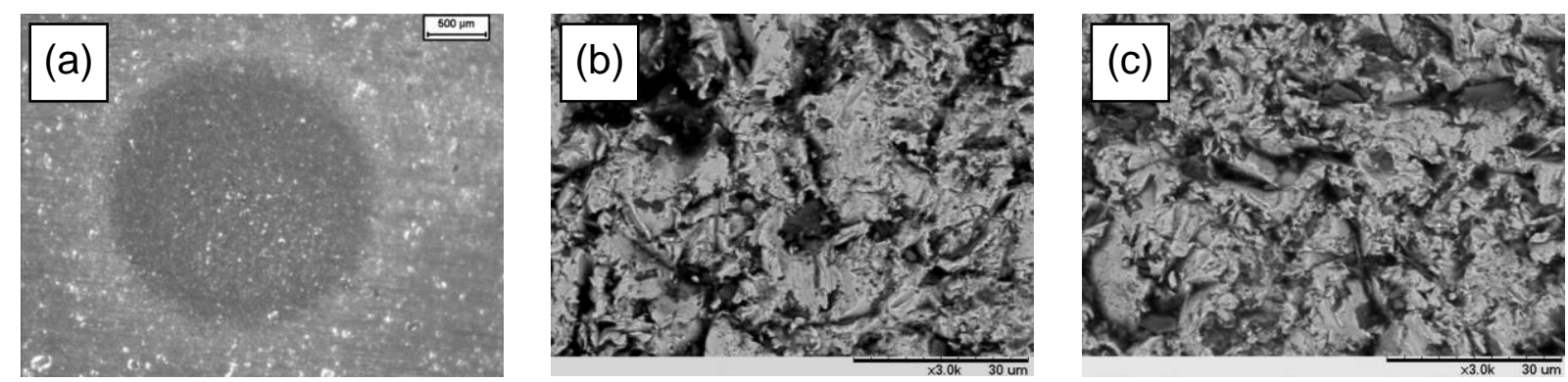

Figure 8. (a) Example of a wear crater generated during the micro-abrasive wear tests $\left(T e_{1}=29^{\circ} \mathrm{C}\right)$ and the occurrence of rolling abrasion for the conditions of (b) $T e_{1}=29^{\circ} \mathrm{C}$ and (c) $T e_{2}=250^{\circ} \mathrm{C}$.

In all test conditions, the wear craters exhibited rolling abrasion, independent of the sliding distance and temperature. These results are in qualitative agreement with the results in the literature [8,30-32], including reports that low values of normal forces and high values of abrasive slurries concentrations favour the occurrence of rolling abrasion. These results particularly agree with the works of Trezona et al. [8] and Adachi and Hutchings [31,32] in which, in addition to an analysis including the normal force and abrasive slurry concentration, there is a relationship between the abrasive wear modes, the average particle size and the properties of the materials involved in the abrasive wear process $(H-$ hardness, $E-$ Young's Modulus and $v$ - Poisson's coefficient, for example). In addition, Allsopp and Hutchings [33] also reported the occurrence of rolling abrasion in tests conducted under a temperature of up to room temperature $\left(T e=350^{\circ} \mathrm{C}\right)$.

\footnotetext{
* Technical contribution to the $2^{\text {nd }}$ International Brazilian Conference on Tribology - TriboBR 2014, November $3^{\text {rd }}$ to $5^{\text {th }}$, 2014, Foz do Iguaçu, PR, Brazil.
} 


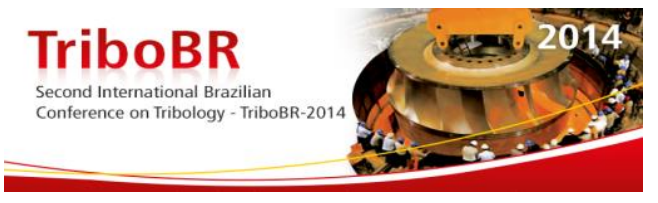

The greater propensity of rolling abrasion action in the tests conducted under elevated temperature can be explained by the fact that upon increasing the temperature, the specimen material became more ductile, facilitating its indentation by the $\mathrm{SiC}$ abrasive particles.

\subsection{Behavioural Analysis of the Coefficient of Friction}

Figure 9 presents the graphics of the coefficient of friction $(\mu)$ as a function of the test time $(t)$ and temperature $(T e)-\mu=f(t, T e)$.

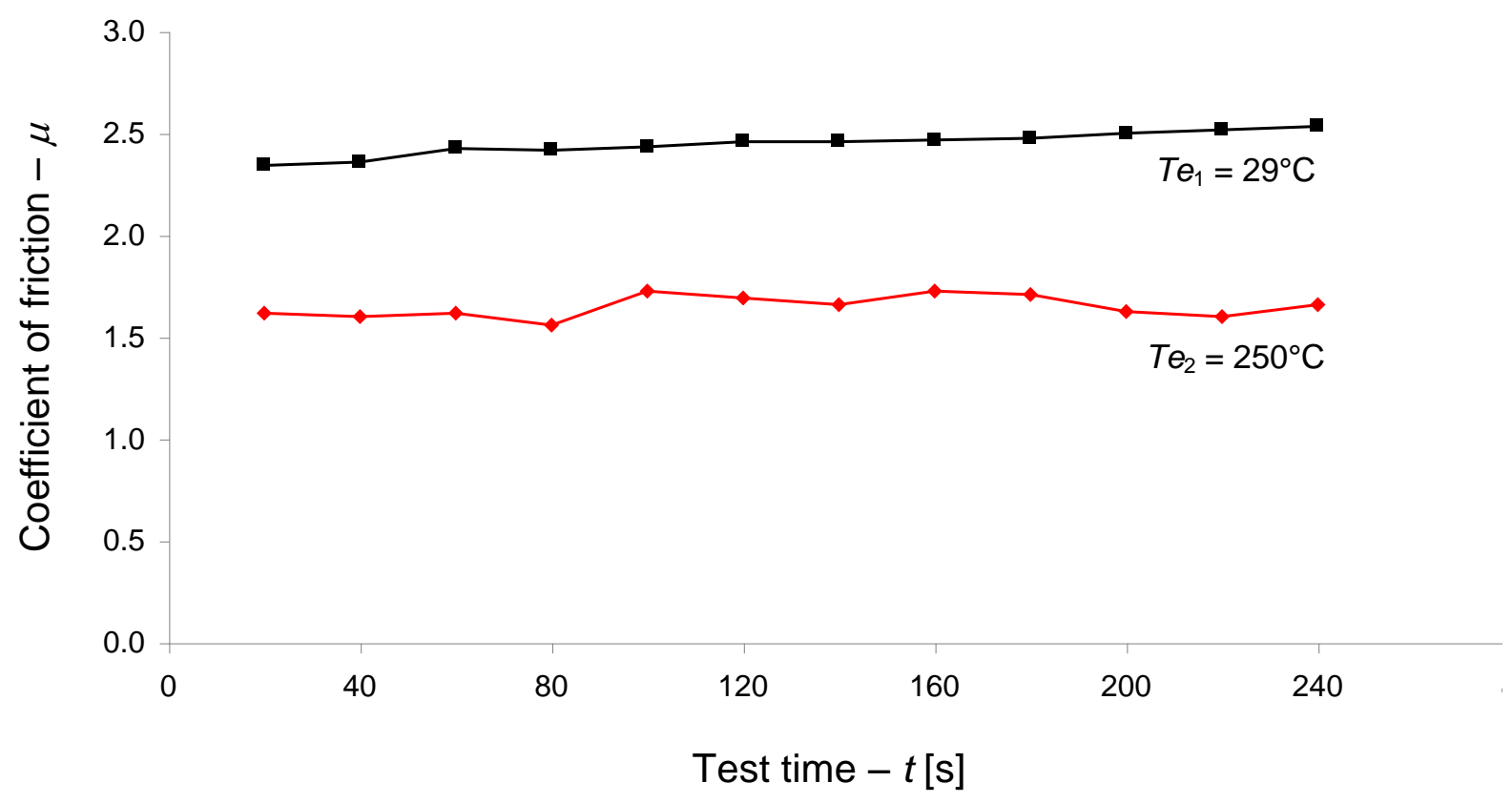

Figure 9. Graphics of the coefficient of friction $(\mu)$ as a function of the test time $(t)$ and temperature $(T e)-\mu=f(t, T e)$. Maximum error observed: $\mu=0.32$.

Note that, independent of the test condition, the coefficient of friction tended to a constant behaviour as a function of the test time and temperature.

The temperature significantly influenced the values of the coefficient of friction, and in a general overview, the coefficient of friction obtained under $T e_{1}=29^{\circ} \mathrm{C}$ was found to be greater than the values of $\mu$ obtained under $T e_{2}=250^{\circ} \mathrm{C}$.

There are two explanations for this behaviour:

a) With the increase in the temperature, the specimen material becomes more ductile; thus, a greater amount of abrasive particles is required to rub on a wear region to remove the same quantity of material. In addition, an abrasive particle is more likely to cut at room temperature, while an abrasive particle just deforms plastically under an elevated temperature;

b) With the increase in the temperature, the viscosity of the glycerin decreased, facilitating the movement of the abrasive particles and, consequently, decreasing the coefficient of friction.

* Technical contribution to the $2^{\text {nd }}$ International Brazilian Conference on Tribology - TriboBR 2014, November $3^{\text {rd }}$ to $5^{\text {th }}$, 2014, Foz do Iguaçu, PR, Brazil. 


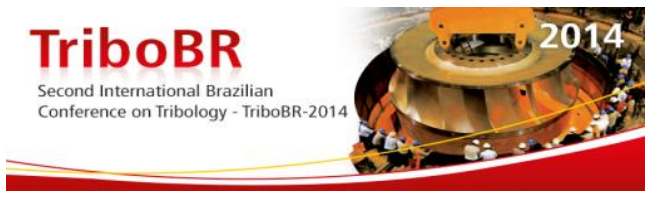

\section{CONCLUSIONS}

Two points can be highlighted in this research:

(i) The temperature significantly influences the tribological behaviour of the Fe30AICr iron aluminide alloy studied: as the temperature increased, the wear resistance of the alloy increased;

(ii) Wear volume and coefficient of friction: as the temperature increased, the wear volume and the coefficient of friction decreased due to the higher ductility acquired by the material specimen and lower viscosity of the glycerin.

\section{Acknowledgements}

The authors gratefully acknowledge Prof. Ana Helena de Almeida Bressiani, from the Nuclear and Energetic Research Institute, for help with the abrasive particle size distribution analysis.

\section{REFERENCES}

1 Cozza RC. Wear coefficient and wear modes transition study in micro-abrasive wear testing [M.Sc. dissertation]. São Paulo: Polytechnic School of the University of São Paulo; 2006. Available online: http://www.teses.usp.br/.

2 Cozza RC. Wear and coefficient of friction study in micro-abrasive wear tests with rotating ball under conditions of "constant normal force" and "constant pressure" [doctor thesis]. São Paulo: Polytechnic School of the University of São Paulo; 2011. Available online: http://www.teses.usp.br/.

3 da Silva Júnior. WM. Effect of pressing pressure and iron powder size on the microabrasion of steam-oxidized sintered iron [M.Sc. dissertation]. Uberlândia: Federal University of Uberlândia; 2003.

4 Rutherford KL, Hutchings IM. Theory and application of a micro-scale abrasive wear test. Journal of Testing and Evaluation - JTEVA. 1997; 25 (2): 250-260.

5 Cozza RC, Tanaka DK, Souza RM. Friction coefficient and abrasive wear modes in ballcratering tests conducted at constant normal force and constant pressure - Preliminary results. Wear. 2009; 267: 61-70.

6 Cozza RC, de Mello JDB, Tanaka DK, Souza RM. Relationship between test severity and wear mode transition in micro-abrasive wear tests. Wear. 2007; 263: 111-116.

7 Cozza RC. Effect of pressure on abrasive wear mode transitions in micro-abrasive wear tests of WC-Co P20. Tribology International. 2013; 57: 266-271.

8 Trezona RI, Allsopp DN, Hutchings IM. Transitions between two-body and three-body abrasive wear: influence of test conditions in the microscale abrasive wear test. Wear. 1999; 225-229: 205-214.

9 Deevi SC, Sikka VK. Nickel and iron aluminides: an overview on properties, processing, and applications. Intermetallics. 1996; 4: 357-375.

10 Schneibel JH, George EP, Anderson IM. Tensile ductility, slow crack growth, and fracture mode of ternary B2 iron aluminides at room temperature. Intermetallics. 1997; 5: 85-193.

11 Morris DG. Possibilities for high-temperature strengthening in iron aluminides. Intermetallics. 1998; 6: 753-758.

12 Stein F, Schneider A, Frommeyer G. Flow stress anomaly and order-disorder transitions in $\mathrm{Fe}_{3} \mathrm{Al}$-based Fe-Al-Ti-X alloys with $\mathrm{X}=\mathrm{V}, \mathrm{Cr}$, Nb, or Mo. Intermetallics. 2003; 11: 7182.

13 Dobeš F, Milička K. Estimation of ductility of Fe-Al alloys by means of small punch test. Intermetallics. 2010; 18: 1357-1359.

\footnotetext{
* Technical contribution to the $2^{\text {nd }}$ International Brazilian Conference on Tribology - TriboBR 2014, November $3^{\text {rd }}$ to $5^{\text {th }}$, 2014, Foz do Iguaçu, PR, Brazil.
} 




14 Bystrzycki J, Fraczkiewicz A, Lyszkowski R, Mondon M, Pakiela Z. Microstructure and tensile behavior of Fe-16Al-based alloy after severe plastic deformation. Intermetallics. 2010; 18: 1338-1343.

15 Morris DG, Morris-Muñoz MA. The influence of microstructure on the ductility of iron aluminides. Intermetallics. 1999; 7: 1121-1129.

16 Wu D, Baker I, Munroe PR, George EP. The yield strength anomaly of single-sliporiented Fe-Al single crystals. Intermetallics. 2007; 15: 103-107.

17 Krein R, Schneider A, Sauthoff G, Frommeyer G. Microstructure and mechanical properties of $\mathrm{Fe}_{3} \mathrm{Al}-$ based alloys with strengthening boride precipitates. Intermetallics. 2007; 15: 1172-1182.

18 Hanus P, Bartsch E, Palm M, Krein R, Bauer-Partenheimer K, Janschek P. Mechanical properties of a forged Fe-25Al-2Ta steam turbine blade. Intermetallics. 2010; 18: 13791384.

19 Risanti DD, Sauthoff G. Microstructures and mechanical properties of Fe-Al-Ta alloys with strengthening Laves phase. Intermetallics. 2011; 19: 1727-1736.

20 Morris DG, Chao J, Garcia Oca C, Muñoz-Morris MA. Obtaining good ductility in an FeAl intermetallic. Materials Science and Engineering A. 2003; 339: 232-240.

21 Cinca N, Lima CRC, Guilemany JM. An overview of intermetallics research and application: Status of thermal spray coatings. Journal of Materials Research and Technology. 2013; 2 (1): 75-86.

22 Borges DFL. Processing and characterization of iron aluminides made from recycled raw material [M.Sc. dissertation]. São Paulo: Polytechnic School of the University of São Paulo; 2010. Available online: http://www.teses.usp.br/.

23 Cozza RC, Tanaka DK, Souza RM. Micro-abrasive wear of DC and pulsed DC titanium nitride thin films with different levels of film residual stresses. Surface and Coatings Technology. 2006; 201: 4242-4246.

24 Cozza RC, Tanaka DK, Souza RM. Friction coefficient and wear mode transition in micro-scale abrasion tests. Tribology International. 2011; 44: 1878-1889.

25 Cozza RC. A study on friction coefficient and wear coefficient of coated systems submitted to micro-scale abrasion tests. Surface \& Coatings Technology. 2013; 215: 224-233.

26 Cozza RC. Influence of the normal force, abrasive slurry concentration and abrasive wear modes on the coefficient of friction in ball-cratering wear tests. Tribology International. 2014; 70: 52-62.

27 Bose K, Wood RJK. Optimum tests conditions for attaining uniform rolling abrasion in ball cratering tests on hard coatings. Wear. 2005; 258: 322-332.

28 Axén N, Jacobson S, Hogmark S. Influence of hardness of the counterbody in threebody abrasive wear - an overlooked hardness effect. Tribology International. 1994; 27 (4): 233-241.

29 Fang L, Liu W, Du D, Zhang X, Xue Q. Predicting three-body abrasive wear using Monte Carlo methods. Wear. 2004; 256: 685-694.

30 Mergler YJ, Huis in 't Veld AJ. Micro-abrasive wear of semi-crystalline polymers. Tribology and Interface Engineering Series. 2003; 41: 165-173.

31 Adachi K, Hutchings IM. Wear-mode mapping for the micro-scale abrasion test. Wear. 2003; 255: 23-29.

32 Adachi K, Hutchings IM. Sensitivity of wear rates in the micro-scale abrasion test to test conditions and material hardness. Wear. 2005; 258: 318-321.

33 Allsopp DN, Hutchings IM. Micro-scale abrasion and scratch response of PVD coatings at elevated temperatures. Wear. 2001; 251: 1308-1314.

\footnotetext{
* Technical contribution to the $2^{\text {nd }}$ International Brazilian Conference on Tribology - TriboBR 2014, November $3^{\text {rd }}$ to $5^{\text {th }}, 2014$, Foz do Iguaçu, PR, Brazil.
} 